\title{
THERAPEUTIC EFFECT OF PROAFTOL IN TREATMENT OF RECURRENT APHTHOUS STOMATITIS
}

\section{Aneta Atanasovska Stojanovska ${ }^{1}$, Mirjana Popovska ${ }^{1}$, Ilijana Muratovska ${ }^{2}$, Kristina Mitic ${ }^{1}$, Emilija Stefanovska $^{1}$, Vera Radojkova Nikolovska ${ }^{1}$}

${ }^{1}$ Department of Oral Pathology and Periodontology, University Dental Clinical Centre \pm Skopje, Faculty of Dentistry, Ss. Cyril and Methodius University, Skopje, R. Macedonia

${ }^{2}$ Department of Cariology and Endodontics, University Dental Clinical Centre \pm Skopje, Faculty of Dentistry, Ss. Cyril and Methodius University, Skopje, R. Macedonia

Corresponding Author: Aneta Atanasovska Stojanovska DDS MSC, PhD Professor at Department of Oral Pathology and Periodontology, University Dental Clinical Centre \pm Skopje, Faculty of Dentistry, Ss. Cyril and Methodius University, Skopje, R. Macedonia, Tel: +389 (0)2 32990 41; E-mail anetaatanasovska@yahoo.com

\begin{abstract}
Recurrent aphthous stomatitis (RAS) is a quite frequent, painful, ulcerative disease that affects the lining of the oral cavity and has an unknown etiology. The aim of this article is to examine the impact of the medication proaftol on epithelization speed and severity of pain in patients with RAS. In this randomized, double-blind, placebo-controlled study respondents were divided into two groups where one group was treated with proaftol spray and the other with a placebo. Aphthae considered for treatment had a diameter of $5 \pm 6 \mathrm{~mm}$. The participants were given instruction on the use of the spray, two sprayings on the place of the aphtae $3 \pm 4$ times a day. We examined two parameters in the symptomatology of RAS-lesion size $(\mathrm{mm})$ and pain intensity (noted on four subjective levels: 0-no pain, 1-discomfort, 2-moderate pain, 3-severe pain). These parameters were noted on the baseline, the third, the fifth and the eighth days of examination.

Results: A significant faster reduction of the dimension of aphthous ulcers in patients treated with proaftol 3rd day $\mathrm{p}<0.001$, 5th day $\mathrm{p}<0.0006$, 8th day full epithelization in the control group. The magnitude of pain in the experimental compared with the control group on 3rd, 5th and 8th day was also significantly reduced: $\mathrm{p}<0.0001, \mathrm{p}<0.007, \mathrm{p}<0.007$ respectively.

Conclusion: The use of proaftol positively influences the rate of epithelization and reduction of subjective feeling of pain in patients with RAS. The action of propolis should be the goal of studies with a larger number of subjects.
\end{abstract}

Key words: Recurrent aphthous stomatitis, propolis, aphthous ulcers.

\section{Introduction}

Recurrent aphthous stomatitis is a common condition that affects about 20 percent of the adult population $[11,18]$. It is a painful ulcerative inflammatory change of the oral mucosa which is not keratinized and causes painful problems during chewing, swallowing and talking. The clinical outcome begins with a subjective feeling of burning and localized pain $24 \pm 48$ hours before the occurrence of a so-cal- led ulcer. The changes resemble round ulcers with a necrotic centre covered with pseudomembranous patches and surrounded by an erythema halo around the edges [25]. The prevalence of this disease is slightly higher in male patients than in female and in patients with higher socioeconomic status. 80 percent of cases of RAS occur before the age of 30 years [24]. Since definitive etiology is unknown, treatment of aphthous ulcers is usually diverse and adapted to 
the conditions and frequency of occurrence for each patient individually. The goals of therapy are aimed at reducing symptoms, reducing the number and size of ulcers, and increasing the periods of remission between two expressions of the disease $[22,23]$. There is no drug that can completely reduce the pain or accelerate epithelization of ulcers when applied topically, and systemic medications can have serious side effects and still not be effective in reducing the frequency of this disease. Propolis is used as a natural antibiotic, thanks to the presence of flavonoids, and in vitro studies have shown antimicrobial major activities, able to neutralise free radicals, activation of the immune system and numerous antioxidant properties $[1,7,8,10]$. Its antibacterial action is directed towards 74 to 19 different species of pathogenic and nonpathogenic bacterial species [19], species of Staphylococcus and 10 species of Streptococcus, Enterococcus, Proteus and Mycobacterium Tuberculosis). As such, propolis is used in the treatment of a variety of inflammatory and ulcerative conditions, with a low rate of minimal side-effects, including contact dermatitis [16].

Propolis also neutralises herpes simplex virus and influenza A2 virus, like all pathogenic species of candida, and also does not destroys the normal flora in the oral cavity and causes resistance to bacteria. The anti-inflammatory effect of propolis is also very important [13].

Flavonoids strengthen capillary walls and strengthen the relationship of serum proteins with histamine, thus eliminating the inflammatory action of histamine, and have antioxidant capabilities. Propolis prevents a connection of vitamin $\mathrm{C}$ to metals and protects intercellular substances. The use of propolis for the treatment of ulcers in the mouth was the practice in some countries of the Middle East [17]. In a preliminary study by Samet, patients who took $500 \mathrm{mg}$ daily supplement of propolis showed a statistically significant reduction in the frequency of the clinical expression of RAS [22].

Proaftol bio complex is a complex of plant anti-inflammatory substances contained in propolis and essential oils.

Wishing to investigate the effect of proaftol on the epithelization of aphthous ulcers and painful subjective sensations we set the hypothesis that application of topical spray proaftol on aphthous ulcers will have a positive effect on epithelization and faster pain relief in these patients, tested against a placebo.

\section{Material and method}

Our study included 20 patients aged 2030 years, who came to the Department of Oral Pathology and Periodontology at the University Clinic in Skopje for treatment of RAS. Based on anamnesis and objective clinical findings the patients were diagnosed with recurrent aphthous stomatitis. We considered only patients with RAS with a frequency of at least 3-4 times a year which was not associated with some common conditions such as anaemia, vitamin deficiency of different origin, inflammatory bowel disease, celiac disease, Morbus Behçet, Reiter's syndrome or any drug which induced immunosuppression and immunodeficiency. We chose 44 aphthae lesions from all patients and divided them into two groups which had two different treatments (one group with proaftol spray and the other group with a placebo spray) Respondents were informed that there are suggestions that propolis may have a role in reducing pain and accelerates epithelization of aphthous changes in RAS. They were also informed of the possible occurrence of an allergic reaction and instructions to stop the application of proaftol in this case were given. Respondents were told that they could receive either propolis or placebo spray, which would be notified at the end of the study.

Respondents were divided into two groups randomly, a group treated with propolis spray (examined group) and a group treated with a placebo effect (control group) which was a dietary supplement based on calcium. This study was based on a double-blind trial and neither participants nor investigators knew the identity of the drugs distributed. The researchers received repacked spray bottles which differed only in colour and which remained unidentified until the final statistical data was obtained from the study.

Respondents were aged 20-30 years old and the aphthous ulcers involved in the investigation, or considered for treatment, had a diameter of 5-6 mm. All participants in the study were given instruction on the use of spray: two sprayinga at the place of the aphtae, 3-4 times a day, half an hour before eating. This study examined two parameters - lesion size expres- 
sed in millimetres and intensity of pain which were noted at four subjective levels 0 -no pain, 1-discomfort, 2-moderate pain, 3-severe pain. These parameters were noted on the first, third, fifth and eighth days of examination.

Apimel (Dr Bacheff) Proaftol spray manufactured in Ohrid, Macedonia, contains in its composition $25 \%$ dry matter propolis etheric oils from sage mint and anise and menthol mixed in $100 \mathrm{ml}$ of diluted alcohol.

The composition of propolis was an inhibitor against Staphilococus aureus, minimum $62.5 \%$, Balm (extract with $70 \%$ etanol) $55.0 \%$, $24.2 \%$ total phenols, total flavone and flavonol $8.0 \%$ and total flavonones and dihidroflavonols $49 \%$.

\section{Results}

After the examination of both set parameters and after statistical processing of the data, we obtain the following results.

The size of the lesion in subjects on the first day of testing in the experimental group was $5.7 \mathrm{~mm}$ compared with the control group, whose value amounted to $5.6 \mathrm{~mm}$, which difference is not statistically significant. On the third day, the average size of the lesion in the experimental group was $3.4 \mathrm{~mm}$ and in the control group $4.6 \mathrm{~mm}$, which showed a statistically significant difference of $p<0.001$. Measurements conducted on the fifth day showed that after using the spray the average size of the lesion in the experimental group was $1.1 \mathrm{~mm}$, compared with the control group where this value amounted $2.2 \mathrm{~mm}$, indicating a high statistical significance of $p<0.0006$. On the eighth day of the trial there were no visible lesions on the oral mucosa in patients treated with propolis, while in the control group the average size of aphthous ulcers was $0.7 \mathrm{~mm}$, with a high significance of $p<0.004$. These results are shown in Table 1.

\section{Table 1}

Lesion size in control versus investigated group on $3^{\text {rd }}$, $5^{\text {th }}$ and $8^{\text {th }}$ days

\begin{tabular}{|c|c|c|}
\hline $\begin{array}{c}\text { 3rd } \\
\text { day }\end{array}$ & Control group & Examinee group \\
\hline $\mathrm{x}$ & 4.600 & 3.400 \\
\hline $\mathrm{sd}$ & 0.516 & 0.843 \\
\hline $\mathrm{df}$ & & 18 \\
\hline $\mathrm{t}$ & & 3.837 \\
\hline $\mathrm{p}$ & & $0.001 * * *$ \\
\hline
\end{tabular}

\begin{tabular}{|c|c|c|}
\hline $\begin{array}{c}5 \text { th } \\
\text { day }\end{array}$ & Control group & Examinee group \\
\hline $\mathrm{x}$ & 2.200 & 1.100 \\
\hline $\mathrm{sd}$ & 0.632 & 0.567 \\
\hline $\mathrm{df}$ & & 18 \\
\hline $\mathrm{t}$ & & 4.093 \\
\hline $\mathrm{p}$ & & $0.0006 * * *$ \\
\hline
\end{tabular}

\begin{tabular}{|c|c|c|}
\hline $\begin{array}{c}\text { 8th } \\
\text { day }\end{array}$ & Control group & Examinee group \\
\hline $\mathrm{x}$ & 0.700 & 0.00 \\
\hline $\mathrm{sd}$ & 0.674 & 0.00 \\
\hline $\mathrm{df}$ & & 18 \\
\hline $\mathrm{t}$ & & 3.279 \\
\hline $\mathrm{p}$ & & $0.004 * * *$ \\
\hline
\end{tabular}

The size of the lesions expressed in percentage of days is shown on the graphs that follow.

Graph 1 e shows the percentage relationship of the sizes of the lesions where it is seen that at the beginning of the trial $30 \%$ of aphthae examined had a dimension of $5 \mathrm{~mm}$, and $70 \%$ the size of $6 \mathrm{~mm}$ in all aphtous lesion.

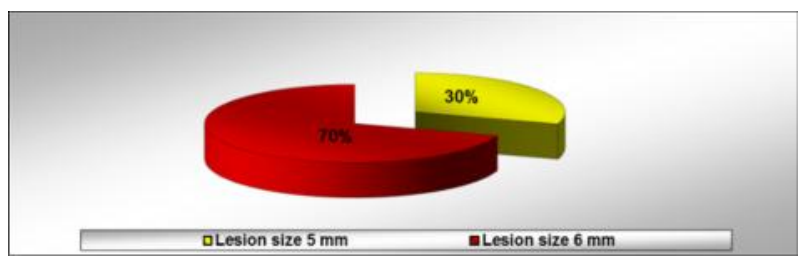

Graph 1 - Percentage of aphthous ulcers in terms of their dimensions expressed in $\mathrm{mm}$ at the beginning of the experimental period (both groups)

Graph 2 shows the percentage and the relationship of the sizes of the lesions which show that on day 3 of the test and $10 \%$ of the surveyed sprue had a dimension of $2 \mathrm{~mm}, 50 \%$ lesion of $3 \mathrm{~mm}, 30 \%$ of $4 \mathrm{~mm}$ and $10 \%$ of $5 \mathrm{~mm}$.

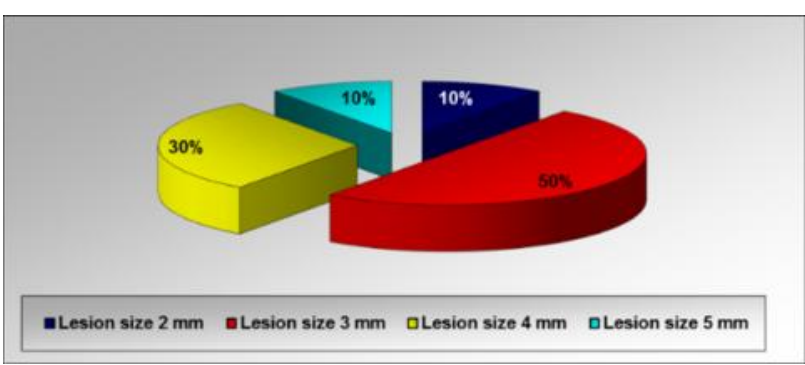

Graph 2 - Percentage of aphthous ulcers in terms of their dimensions expressed in mm on day 3 in the experimental group (examined group)

Graph 3 shows lesion size in percentage in patients treated with proaftol on the fifth day of the test and $10 \%$ had no visible lesion of the oral mucosa, $70 \%$ had a lesion size $1 \mathrm{~mm}$ and $20 \%$ of $2 \mathrm{~mm}$. 


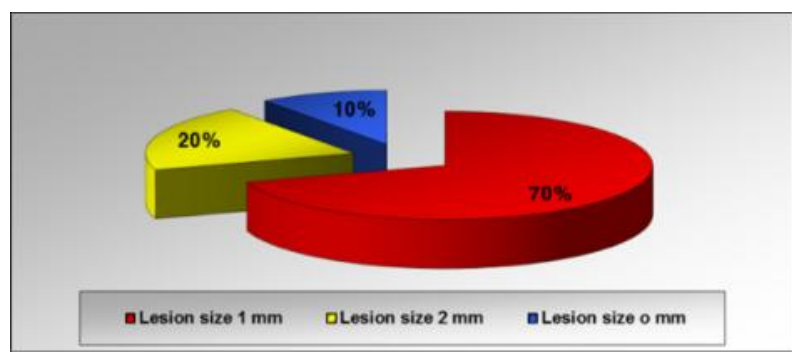

Graph 3 - Percentage of aphthous ulcers in terms of their dimensions expressed in mm on day 5 (examined group)

Graph 4 shows lesion size in percentage in patients treated with a placebo on the first day of the examination which was not statistically significantly different from the group of patients treated with proaftol.

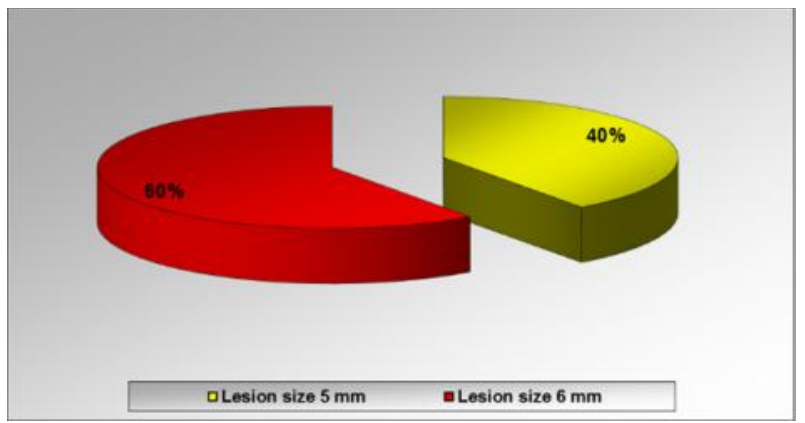

Graph 4 - Lesion size expressed in percentage for the first day in patients with placebo treatment

Graph 5 shows the sizes of the lesions in the control group in percentage, where can see that on the third day of the examination $40 \%$ of the surveyed sprue had a dimension of $4 \mathrm{~mm}$, while $60 \%$ of aphthous ulcers had the dimensions of $5 \mathrm{~mm}$.

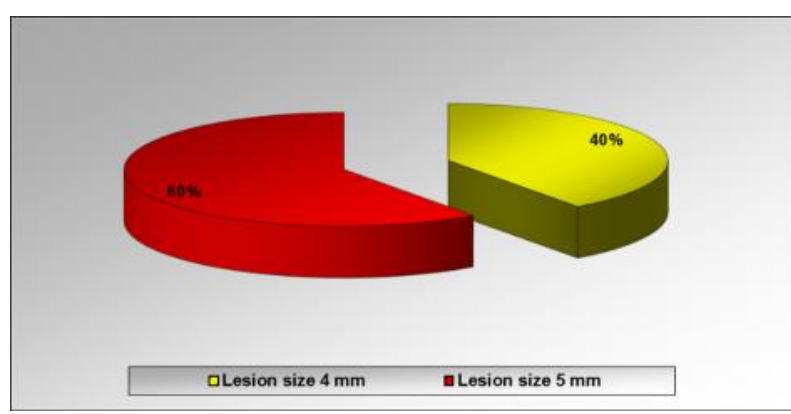

Graph 5 - Percentage of aphthous ulcers in terms of their dimensions expressed in mm on day 3 of the examination (control group)

Graph 6 shows the size of the lesion in of placebo-treated patients on the fifth day of the test in percentage, and $10 \%$ had lesions on the oral mucosa of $1 \mathrm{~mm}, 60 \%$ had a lesion of $2 \mathrm{~mm}$ and $30 \%$ of $3 \mathrm{~mm}$.

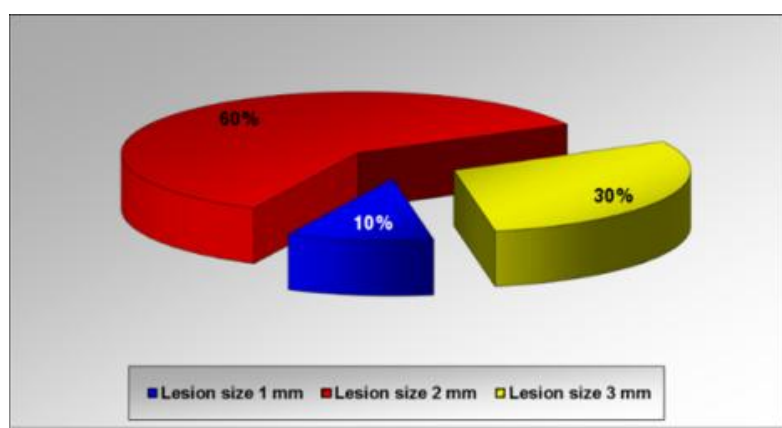

Graph 6-Lesion size expressed in percentage for the fifth day in patients with placebo treatment

Graph 7 shows the lesion size in percentage of patients treated with placebo on the eighth day of the test and $50 \%$ had lesions on the oral mucosa of $1 \mathrm{~mm}, 10 \%$ had a lesion size of $2 \mathrm{~mm}$, and the remaining $40 \%$ had an entire epithelization.

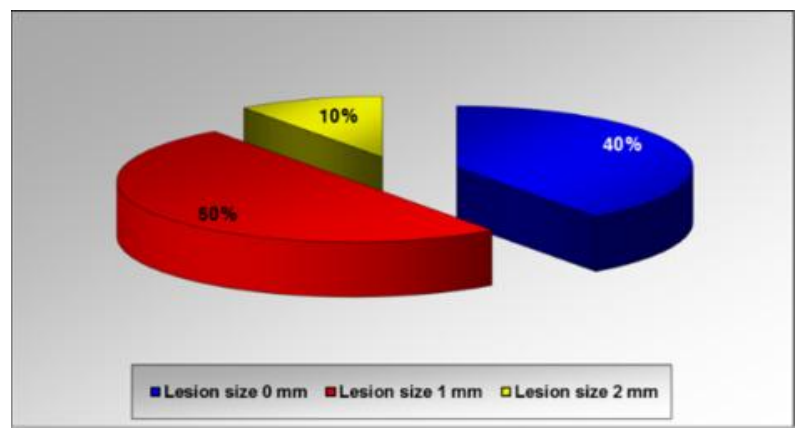

Graph 7 - Lesion size expressed in percentage for the eighth day in patients with placebo treatment

Graph 8 shows a comparative overview of the size of the lesion in the experimental group versus the control over the 8 days.

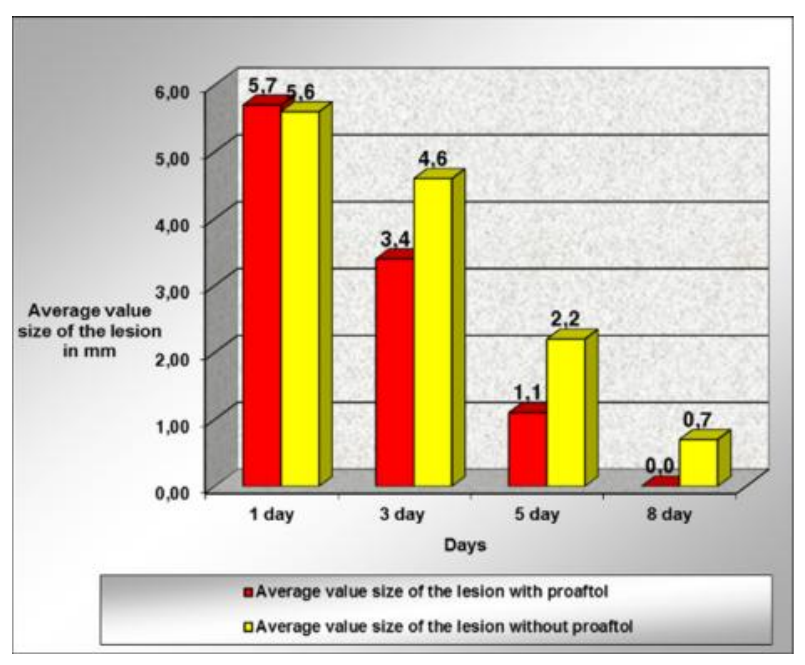

Graph 8-Comparative overview of the size of the lesion in the experimental group compared with the control over the 8 days 
The magnitude of pain in subjects on the first day of testing in the experimental and control group was an average of 3.0, indicating identical painful sensation at the starting point. On the third day, the average feeling of pain was 1.4 in the experimental group and 2.5 in the control group, which shows a statistically significant difference of $\mathrm{p}<0.001$.

Examinations conducted after the fifth day using the spray show that the scale of pain was 1 (discomfort) that means discomfort, compared with the control group where this value was about 1.5 (moderate pain), indicating a high statistical significance of $p<0.007$. On the eighth day of the trial there were no visible lesions on the oral mucosa in the patients treated with propolis, and accordingly there was no finding of any painful sensation, as opposed to the control group where discomfort still existed in some of the surveyed sprue. This difference was statistically significant: $p<0.007$. The results are shown in Table 2

Table 2

Strength of pain in the examined versus the control group on $3 \mathrm{rd}$, 5th and 8th day of the examination

\begin{tabular}{|c|c|c|}
\hline \multirow{3}{*}{$3 \mathrm{rd}$} & Control group & Examinee group \\
\cline { 2 - 3 } $\mathrm{x}$ & 2.500 & 1.400 \\
\cline { 2 - 3 } $\mathrm{sd}$ & 0.527 & 0.516 \\
\cline { 2 - 3 } $\mathrm{df}$ & & 18 \\
\cline { 2 - 3 } $\mathrm{t}$ & & 4.714 \\
\cline { 2 - 3 } $\mathrm{p}$ & & $0.0001 * * *$ \\
\hline
\end{tabular}

\begin{tabular}{|c|c|c|}
\hline \multirow{3}{*}{5 th } & Control group & Examinee group \\
\cline { 2 - 3 } $\mathrm{x}$ & 1.500 & 1.00 \\
\cline { 2 - 3 } $\mathrm{sd}$ & 0.527 & 0.00 \\
\cline { 2 - 3 } $\mathrm{df}$ & & 18 \\
\cline { 2 - 3 } $\mathrm{t}$ & & 3.00 \\
\cline { 2 - 3 } $\mathrm{p}$ & & $0.007 * * *$ \\
\hline
\end{tabular}

\begin{tabular}{|c|c|c|}
\hline 8th & Control group & Examinee group \\
\cline { 2 - 3 } $\mathrm{x}$ & 1.500 & 0.00 \\
\cline { 2 - 3 } $\mathrm{sd}$ & 0.527 & 0.00 \\
$\mathrm{ndy}$ & & 18 \\
\cline { 2 - 3 } $\mathrm{t}$ & & 3.00 \\
\cline { 2 - 3 } $\mathrm{p}$ & & 0.007 *** \\
\cline { 2 - 3 } & & \\
\hline
\end{tabular}

Graph 9 shows the comparative summary of pain intensity in the experimental group compared with the control group over the period of 8 days.

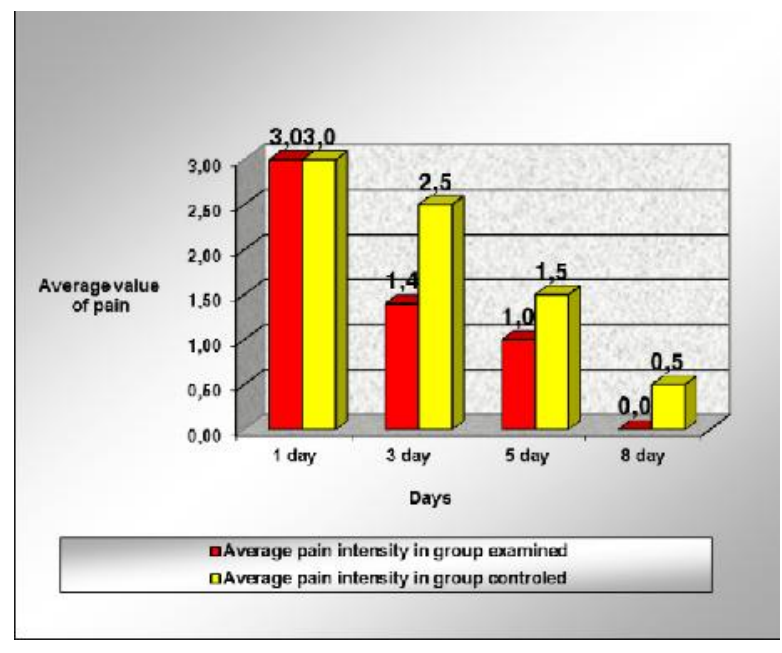

Graph 9 - The comparative summary of pain intensity in the experimental group compared with the control group over the period of 8 days

0-no pain, 1-discomfort, 2-moderate pain, 3severe pain

\section{Discussion}

Recurrent aphthous stomatitis is a disease that is expressed quite individually in each patient in terms of what triggers its initiation and frequency of occurrence in the course of a year. There is no known etiology and no exact or precise protocol in the treatment and prevention of occurrence of aphthous ulcers or in how to relieve pain and speed up epithelization. This was the reason why we used propolis in this study in the treatment of RAS in order to examine its influence on epithelization and pain relief of aphthous changes in our patients. The antimicrobial properties of propolis were documented during the $70 \mathrm{~s}$ of the last century and it was proved that it affects more than a gram + gram - microbes [5]. The anti-inflammatory effect of propolis is also very important. Flavonoids (mainly pinocembrin enabled) will not only have an inhibitory effect on bacteria and fungi but also strengthen capillary walls and strengthen the relationship of serum proteins with histamine, thus eliminating the inflammatory effect of histamine. Flavonids also have the effect of an antioxidant. Propolis prevents a connection of vitamin $\mathrm{C}$ to metals and protects intercellular substance [3].

Propolis extract is active against a wide range of dermatophytes in concentrations of $0.25-2 \%$ and its antiviral effect against some protozoa incubated for 24 hours with $150 \mathrm{mi}-$ crograms per millilitre propolis is proved. [21] 
Caffeic acid phenetil ester (CAPE) which is extracted from propolis proved toxic to tumour cells in the body [21]. 3, 5, 7-trihydroxiflavine (galangain) another falvonoid of propolis is also shown as an active component in the suppression of Bacillus suptilis [6]. Propolis neutralizes herpes simplex virus and influenza virus A2 and all pathogenic species of Candida. Propolis does not destroy the normal flora in the oral cavity and causes resistance to bacteria.

Chromatographic tests made of bacteria and fungi in agar medium proved that propolis contains more than one ingredient active against Candida albicans and gram + bacteria. One study has found that one yet unidentified component of propolis which is soluble in water inhibits bacterial DNA-dependent RNA polymerase [4].

In our study it showed a statistically significant reduction of aphthous lesions in subjects who used propolis compared with the placebo group on the third day from the commencement of the trial $(p<0.001)$ and successively rapidly decreased significantly more compared with the placebo group. A very important fact was that on the eighth day patients who used propolis did not have a visible lesion which was not the case with the other group of respondents.

Honey was used as a means in faster healing of wounds. Ethanol, which is one of the propolis extracts, has been proven in various studies as a means to help the regeneration of bone, cartilage and dental pulp [12]. Flavonoids that propolis contains have an anti-inflammatory activity because of their proven ability to participate in the stimulation of collagen formation [13]. Apart from its antiviral, antibacterial and antifungicidal action propolis has an immunomodulatory effect that increases the value of properdin in serum and activates alternative pathways for the complement system, regenerates and heals tissue and acts as a local anaesthetic $[2,14,15]$. In our study pain, which is a very important factor that can limit speech, normal diet, and even prevent swallowing in these patients, was significantly reduced in the group of patients who used propolis in the treatment of aphthous ulcers vs. the placebo group ( $\mathrm{p}<0.001)$. Pain intensity among respondents on the first day of testing in the test and control groups had an average value of 3.0. indicating an identical starting position of pain- ful sensation. On the third day the average feeling of pain in was 1.4 the experimental group and 2.5 in the control group, which shows a statistically significant difference of $p<0.001$. Surveys conducted after the fifth day of using the spray gave the following results: the average amount of pain was 1 , which means discomfort, versus 1.5 in the control group, which means moderate pain, suggesting the high statistical significance of $p<0.007$.

Propolis is actually a resin substance that bees produce by collecting different ingredients from plants and serves to defend the hive from various harmful external effects. The chemical composition of propolis is falvonoids, aromatic acids, esters, aldehydes, ketones, fatty acids, terpenes, steroids, amino acids, polysaccharides, alcohol, hydroxybenzene and several other compounds in trace amounts [20]. Propolis inhibits the expression of p24 antigen of HIV-infected T cells 95 and slows down the growth of leukaemia cells in culture [13]. In a study of Samet 19 patients received $500 \mathrm{mg}$ [22] propolis daily for a period of 6 months and as a result had a significant reduction in the number of sprue during exacerbation compared with those patients who received a placebo. Difficulties in the formation of this type of study are the reason why the causes of RAS are unknown, hence by examining the effect of propolis it is not possible to eliminate the etiologic agent or action on the pathogenic mechanism of the disease. However, because of the broad biological composition of propolis there are several possible theories of the way it influences stomatitis aphtous recurens. If we assume that infectious agents cause minor aphthae, then through the antibacterial, antifungal and antiviral effect of propolis we may explain the therapeutic mechanism. If immune factors are crucial in the etiology of the disease, then presumably the flavonoid of propolis acts in pathogenesis. From that point any kind of discussion would go towards speculation. Our study begins with a therapy for the existing aphthae in the mouth and goes with the hypothesis that propolis acts as a pain relief and accelerates epithelization. But the final conclusion and possible input of propolis therapeutic protocol in RAS should be strengthened by conducting studies with a larger number of patients, and a longitudinal multicentre, as well as standardi- 
zing the composition of a form of medical propolis. The variations in its composition could occur as a result of the different features of the bees and the plants they use in the creation of propolis in different geographic areas.

\section{REFERENCES}

1. Banscota $\mathrm{AH}$, et al. Recent progress in pharmacological research of propolis. Phytother Res. 2001; 15: 561-571.

2. Boyanova L, et al. Inhibition of Helicobacter pylori growth in vitro by Bulgarian propolis : preliminary report. J Med Mikrobiol. 2003; 52: 417-419.

3. Cherniak E P. Bugs and drugs Part 1: Insects. The new alternative medicine for the 21 century? Alternative Medicine Review. 2010; 15-2: 124-135

4. Farnesi A.P. Aquino Ferreira R, De Jong D, Bastos J $\mathrm{K}$, Soares AEE. Effects of stingless bee and honey bee propolis on four species of bacteria. Genetics and Molecular Research. 2009; 8-2: 635-640.

5. Grange J.M, Davey R.W. Antibacterial properties of propolis (bee glue) Journal Of The Royal Society of Medicine. 1990; 83: 159-160.

6. Gruneberger D, Banerjee R, Eisinger K, et al. Preferential cytotoxicity on tumor cells by caffeic acid phenetthyl ester isolated from propolis. Experientia. 1988; 44: 230-2.

7. Harborne JB, Wiliams CA (2000) Advances in flavonoid research since. Phytochemistry. 1992; 55: 481-504.

8. Havsteen BH. The biochemistry and medical significance of the flavonides. Pharmacol Ther. 2002; 96: 67-202.

9. Henschel R, Agathos M, Breit R. Occupational contact dermatitis from propolis. Contact Dermatitis. 2002; 47-52.

10. Huleihel M, Ishano V. Effect of propolis extract on malignant cell transformation by moloney murine sarcoma virus. Arch Virol. 2001; 146: 1517-1526.

11. Kerr AR, Ship JA. Management strategies for HIVassociated aphthous stomatitis. Am J Clin Dermatol. 2003; 4: 669-680.

12. Koo H, et al. Effects of compounds found in propolis on Streptococcus mutans growth and on glucosiltranferase activity. Antimicrob Agents Chemoter. 2000; 46: 1302-1309.

13. Kujumgiev A, et al. Antibacterial antifungal and antiviral activity of propolis of different geographical origin. J Ethnopharmacol. 1999; 64: 235-240.

14. La Casa C, et al. Evidence for protective and antioxidant properties of rutin, a natural flavone, against ethanol induced gastric lesions. J Ethnopharmacol. 2000; 71: 45-53.

15. Lewis DA, Shaw GP. A natural flavonoid and synthetic analogues protect the gastric mucosae from aspirin indused erosions. J Nutr Biochem. 2001; 12: 95-100.
16. Maximova-Todorova V, et al. Antiviral effects of some fractions isolated from propolis. Acta Microbiol Bulg. 1985; 17: 79-85.

17. Middleton E, Kandaswami C, Theoharides TC. The effect of plant flavonoids on mammalian cells: implications for inflammation, heart diseases and cancer. Pharmacol Rev. 2000; 52: 673-751.

18. Natahh SS, et al. Recurrent aphthous ulcers today: a review of the growing knowledge. Int J Oral Maxillofac Surg. 2004; 33: 221-234.

19. Pepljnajak S, Jalsenjak J, Maysinger D. Growth inhibition of Bacillus suptilis and composition of various propolis extracts. Pharmazie. 1982; 37: 864-5.

20. Revuz J, Giullaume JC, Janier M, et al. Crossover study of thalidomide vs. placebo in severe recurrent aphthous stomatitis. Arch Dermatol. 1990; 126: 923927.

21. Russo A, Longo R, Vanela A. Antioxidant activity of propolis: role of caffeic acid phenetyl ester and galangin. Fitoterapia. 2002; 73(1): S21-S29.

22 . Samet N, et al. The effect of bee propolis on recurrent aphthous stomatitis: a pilot study Clin Oral Invest. 2007 ; 11: 143-147.

23. Santos FA, et al. Antibacterial activity of Brazilian propolis and fractions against oral anaerobic bacteria. J Ethnopharmacol. 2002; 80: 1-7.

24. Stoopler ET, Sollectio TP. Recurrent aphthous stomatitis update for general practitioner. N Y State Dent J. 2003: 27-29.

25. Scully $\mathrm{C}$, et al. The diagnosis and management of reccurent aphthous stomatitis: a consensus approach. J Am Dent Assoc. 2003; 134: 200-206.

\section{Резиме}
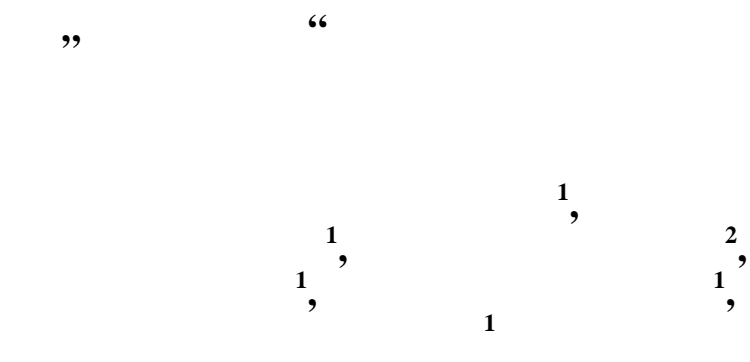

Рекурентниот афтозен стоматитис (РАС) е доста често, болно, улцеративно заболување кое ја зафаќа лигавицата на оралната празнина и има непозната етиологија. Цел на трудот е да се испита влијанието на медикаментот „проафтол“ врз брзината на епителизација и јачината на болка кај пациенти со recurrent aphtous stomatitis (RAS).

Во оваа рандомизирана, дупло слепа, плацебо контролирана студија, испитаниците се поделени во две групи при што една група е третирана со спреј „проафтол“, а другата со пла- 
цебо. Афтите што се вклучени во испитувањето, односно што се земени предвид за третман, беа со дијаметар од 5 до 6 мм. На испитаниците им беше дадена инструкција за употреба на спрејот: две прскања на местото на афтата 3-4 пати дневно. Во оваа студија беа испитувани два параметра: големина на лезијата (мм) и јачина на болката, која беше забележана на четири субјективни нивоа: 0 - нема болка, 1 - слаба болка, 2 - умерена болка, 3 - јака болка. Овие параметри беа евидентирани на денот на прием, третиот, петтиот и на осмиот ден.

езулй $\bar{u} u$. Сигнификантно побрзо намалување на димензијата на афтите кај пациентите третирани со проафтол третиот ден $\mathrm{p}<0,001$, петиот ден $\mathrm{p}<0,0006$, осмиот ден целосна епителизација во однос на контролната група. Јачината на болката кај испитуваната наспроти контролната група третиот, петиот и осмиот ден, исто така, била значително намалена $\mathrm{p}<$ 0,0001, $\mathrm{p}<0,007, \mathrm{p}<0,007$ последователно.

клучок. „Проафтол“ дејствува позитивно на брзината на епителизација и субјективно намаливање на чувството на болка кај пациенти со РАС. Дејството на прополисот треба да биде цел на студии со поголем број испитаници.

лучни зборови: рекурентен афтозен стоматитис, прополис, афтозни улцери. 